Jurnal Natur Indonesia 14(1), Oktober 2011: 19-25

ISSN 1410-9379, Keputusan Akreditasi No 65a/DIKTI/Kep./2008

\title{
Proliferasi Kalus dari Eksplan Hipokotil dan Kotiledon Tanaman Jarak Pagar (Jatropha curcas L.) pada Pemberian 2,4-D
}

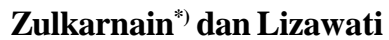 \\ Program Studi Agronomi, Fakultas Pertanian, Universitas Jambi, Jambi 36361 \\ Diterima 23-01-2010Ｄisetujui 06-06-2011
}

\begin{abstract}
The aim of this study was to develop an efficient method for the induction of embryogenic callus formation for in vitro propagation of jatropha. Plant materials used were 30-days old in vitro seedlings, cut into hypocotyl and cotyledon (lower, middle and upper) sections. Medium used was MS composition supplemented with vitamins, $3 \%$ sucrose, $0.7 \%$ agar at pH $5.8 \pm 1$, and 2,4-D (0, 1, 2, 3, 4 dan $\left.5 \mathrm{mg} \mathrm{l}^{-1}\right)$. Cultures were kept at temperature of $25 \pm 1^{\circ} \mathrm{C}$ with $50 \mu \mathrm{mol} \mathrm{m} \mathrm{m}^{-2} \mathrm{~s}^{-1}$ light intensity and $16-\mathrm{h}$ photoperiod. The results indicated that the rate of callus formation depended on the source of explant, the application of 2,4-D, and the interaction of both. The fastest callus proliferation (2.33 days following initiation) was obtained on cotyledon explants cultured on medium without 2,4-D. The explant sources and 2,4-D concentrations also showed significant effect on the percentage of explant forming callus. The most callus formation (88.33\%) was obtained on middle cotyledon cultured on $3 \mathrm{mg} \mathrm{l}^{-1} 2,4-\mathrm{D}$, whereas the fewest (6.84\%) was found on upper cotyledon cultured on medium without 2,4-D. The colour of callus was dominated by white, light yellow, cream and brown with mostly compact structure, particularly on hypocotyl cultured on medium without $2,4-\mathrm{D}$. The texture of callus formed on hypocotyl treated with up to $4 \mathrm{mg} \mathrm{1}^{-1} 2,4-\mathrm{D}$ was dominated by coarse appearance. In contrast, majority of callus proliferated on hypocotyl treated with $5 \mathrm{mg} \mathrm{1}^{-1} 2,4-\mathrm{D}$ or cotyledon treated with or without 2,4-D produced callus with smooth texture.
\end{abstract}

Keywords: callus proliferation, cotyledon, hypocotyl, jatropha

\section{PENDAHULUAN}

Kebutuhan bahan bakar minyak dunia semakin hari semakin meningkat sejalan dengan meningkatnya jumlah penduduk dan kendaraan bermotor, sementara cadangan minyak mentah yang ada sekarang ini semakin berkurang. Ketidakseimbangan antara pasokan dan kebutuhan bahan bakar minyak telah diantisipasi oleh Pemerintah Indonesia dengan memberlakukan kebijakan pengembangan bahan bakar nabati yang dapat diperbaharui dan ramah lingkungan (Krisnamurti 2006), seperti biodiesel.

Dewasa ini telah diketahui sejumlah tanaman yang memiliki potensi sebagai sumber biodiesel, di antaranya adalah jarak pagar (Jatropha curcas). Jarak pagar sangat potensial sebagai sumber bahan bakar alternatif karena kandungan minyaknya cukup tinggi, yakni 4-40\% dari bobot biji, memiliki titik beku yang rendah $\left(3^{\circ} \mathrm{C}\right)$ dan tidak berkompetisi dengan komoditas pangan. Selain itu, minyak jarak memiliki nilai cetane $\left(\mathrm{C}_{16} \mathrm{H}_{34}\right)$ yang tinggi dan dapat dicampur langsung sebagai bahan transesterisasi di dalam minyak diesel serta memiliki daya lumas yang tinggi sehingga dapat memperpanjang usia mesin (Datta et al. 2007). Minyak jarak termasuk kelompok bahan bakar bersih sehingga pemakaiannya dapat mengurangi emisi gas rumah kaca.

*Telp: +628127478972

Email: dr.zulkarnain@yahoo.com
Pengembangan jarak pagar sebagai sumber energi alternatif yang dapat memberikan keuntungan secara ekonomi memerlukan pola pengusahaan komersial dalam skala besar (perkebunan). Pola usaha demikian tentu saja membutuhkan tersedianya bahan tanaman sebagai sumber bibit yang tidak sedikit. Selain itu, bibit tersebut harus berasal dari klon unggul dengan kandungan minyak biji yang tinggi. Ketersediaan bibit ini dapat dipenuhi melalui perbanyakan secara konvensional, yakni secara generatif menggunakan biji atau secara vegetatif menggunakan setek. Akan tetapi perbanyakan dengan biji dan setek dihadapkan pada kendala terbatasnya jumlah biji yang dapat dijadikan benih karena berkompetisi dengan pemanfaatan biji sebagai sumber minyak dan terbatasnya jumlah pohon induk yang dapat dijadikan sebagai sumber setek. Di samping itu, jumlah tanaman yang diregenerasikan juga sangat terbatas, yakni satu setek hanya menghasilkan satu tanaman anak, sehingga menjadikan metoda perbanyakan ini tidak ekonomis untuk skala komersial.

Pendekatan baru dalam perbanyakan tanaman dengan memproduksi embrio somatik melalui teknik mikropropagasi dapat mengatasi kendala-kendala yang dihadapi pada perbanyakan menggunakan biji maupun setek. Menurut Taji et al. (2002), embriogenesis somatik memiliki arti penting di dalam mikropropagasi untuk memproduksi tanaman seragam 
dalam jumlah besar. Diharapkan melalui embriogenesis somatik upaya mendapatkan tanaman jarak pagar yang seragam dalam jumlah besar dan bebas dari penyakit dapat diwujudkan. Proses ini dibatasi oleh banyak hal karena embrio somatik hanya akan berkembang dari massa kalus yang embriogenik dan waktu yang dibutuhkan untuk mendapatkan kalus dengan sifat-sifat embriogenik ada kalanya sangat lama. Di samping itu, faktor-faktor lain seperti hormon tanaman, hara dan kondisi lingkungan harus dioptimasi terlebih dahulu agar embriogenesis dapat berlangsung. Penelitian tentang mikropropagasi jarak pagar telah dilakukan oleh sejumlah peneliti seperti Sujatha dan Muktha (1996), Wei et al. (2004), Rajore dan Batra (2005), Sujatha et al. (2005) dan Novita (2006). Akan tetapi, dari hasil yang didapatkan terungkap bahwa pembentukan embrio somatik masih terbatas sehingga jumlah plantlet yang diregenerasikan juga terbatas.

Penelitian ini bertujuan untuk mendapatkan protokol yang efisien dalam menginduksi proliferasi kalus embriogenik pada kultur in vitro tanaman jarak pagar.

\section{BAHANDANMETODE}

Bahan tanaman yang digunakan pada penelitian ini adalah benih bersertifikat (Nomor KB 525.S/03/BPBTP/2009) yang berasal dari tanaman induk terpilih asal Pakuwon, yang diperoleh dari Pusat Penelitian dan Pengembangan Perkebunan, Balai Penelitian Tanaman Rempah dan Aneka Tanaman Industri, Sukabumi. Sebagai bahan eksplan adalah kecambah in vitro yang berumur lebih-kurang 30 hari. Kecambah in vitro tersebut selanjutnya dipotong dan dibedakan atas hipokotil, kotiledon pangkal, kotiledon tengah dan kotiledon ujung, yang selanjutnya digunakan sebagai bahan eksplan.

Medium kultur yang digunakan adalah komposisi Murashige Skoog (MS) (Murashige \& Skoog 1962), yang dilengkapi dengan vitamin, $3 \%$ sukrosa dan $0,7 \%$ agar-agar dengan $\mathrm{pH} 5,8 \pm 1$. Sementara itu zat pengatur tumbuh yang digunakan adalah 2,4-D dengan berbagai taraf konsentrasi $\left(0,1,2,3,4\right.$ dan $\left.5 \mathrm{mg} \mathrm{l}^{-1}\right)$.

Persiapan eksplan. Sterilisasi permukaan terhadap biji tanaman jarak pagar yang akan dijadikan sebagai bahan eksplan dilakukan dalam dua tahap, yaitu sterilisasi awal yang dilakukan di luar Laminar Air Flow Cabinet (LAFC) dan sterilisasi lanjutan yang dilakukan di dalam LAFC.

Di luar LAFC, biji jarak yang telah dikupas kulitnya dicuci dengan deterjen dan dibilas sampai bersih, lalu kulit arinya dibuang. Selanjutnya biji-biji yang sudah dibuang kulit arinya direndam di dalam larutan $0,1 \% \mathrm{NaOCl}$ selama
1 menit, lalu dibilas sampai bersih dengan air steril. Kemudian biji-biji tersebut direndam di dalam Agrept, Benlate dan Dithane masing-masing 0,2\% (w/v) selama 1 jam, lalu dibawa ke dalam LAFC.

Di dalam LAFC biji-biji direndam di dalam larutan Agrept, Benlate dan Dithane dibilas 3 kali dengan air steril sampai bersih. Selanjutnya biji-biji tersebut direndam lagi di dalam $0,05 \% \mathrm{NaOCl}$ secara bertingkat selama 30, 20 dan 10 menit, dimana antar tingkatan dilakukan pembilasan dengan air steril masing-masing 3 kali. Setelah proses sterilisasi selesai, biji-biji steril dikeringkan pada kertas tisu di dalam cawan petri yang telah disterilkan, sebelum dikulturkan pada medium MS tanpa zat pengatur tumbuh untuk mendapatkan kecambah in vitro. Ke dalam setiap wadah kultur ditanam satu biji, mengingat ukurannya yang relatif besar dan untuk menghindari kerugian akibat kontaminasi.

Penanaman eksplan dan pemeliharaan kultur. Kecambah in vitro yang tumbuh setelah 6 minggu biji ditanam, dikeluarkan dari wadah kultur dan diletakkan pada cawan petri steril. Selanjutnya kecambah tersebut dipotong dan dipisahkan atas hipokotil, kotiledon pangkal, kotiledon tengah dan kotiledon ujung.

Ke dalam wadah kultur yang berisi medium dengan perlakuan yang telah ditetapkan, ditanamkan hipokotil, kotiledon pangkal, kotiledon tengah dan kotiledon ujung yang berasal dari kecambah yang sama. Eksplan yang sudah dikulturkan selanjutnya dipelihara pada rak-rak di dalam

${ }^{0} \mathrm{C}$ dengan intensitas cahaya lebih-kurang $50 \mu \mathrm{mol} \mathrm{m} \mathrm{m}^{-2} \mathrm{~s}^{-1}$ dan fotoperiodesitas $16 \mathrm{jam}$ yang diperoleh dari lampu TL berwarna putih.

Subkultur dilakukan terhadap kultur yang memperlihatkan perkembangan yang prospektif, yaitu kultur yang memproliferasikan kalus embriogenik. Medium yang digunakan pada subkultur memiliki komposisi yang berbeda dari medium untuk inisiasi kultur. Pada subkultur digunakan medium dengan kandungan garam mineral setengah dari normal (MS1/2) atau medium dengan kandungan garam mineral normal (Medium MS0), namun dengan kandungan sukrosa dan agar-agar yang sama, yaitu masing-masing 3 dan $0,8 \%$.

Pengamatan. Pengamatan dilakukan dengan mencermati pertumbuhan dan perkembangan eksplan setiap minggu dengan peubah-peubah yang diamati sebagai berikut:

1. Kecepatan pembentukan kalus, yang dilakukan terhadap lamanya waktu antara inisiasi kultur sampai kalus pertama kali terlihat berproliferasi pada permukaan eksplan. 
2. Persentase eksplan yang membentuk kalus, yang diamati pada akhir penelitian, yaitu dengan menghitung jumlahjumlah hipokotil dan kotiledon yang membentuk kalus dibagi dengan jumlah keseluruhan hipokotil dan kotiledon yang dikulturkan pada perlakuan yang sama.

3. Karakteristik kalus, yang diamati secara visual dengan memperhatikan peubah-peubah warna, struktur dan tekstur.

Data dianalisis secara statistik menggunakan sidik ragam untuk melihat pengaruh sumber eksplan dan tingkat konsentrasi 2,4-D yang diberikan. Sedangkan untuk melihat perbedaan pengaruh antar sumber eksplan dan antar tingkat konsentrasi 2,4-D dilakukan uji beda nyata terkecil (BNT) pada tingkat $\alpha=5 \%$. Sementara itu, peubah yang tidak dapat diukur secara kuantitatif, diamati secara kualitatif dan analisis dilakukan secara deskriptif.

\section{HASIL DAN PEMBAHASAN}

Pembentukan kalus dari jaringan eksplan yang dikulturkan dalam suatu sistem kultur in vitro melibatkan perkembangan sel yang berlangsung secara acak dan tidak merata, di samping keterlibatan sel-sel yang belum terspesialisasi dan hilangnya struktur sel-sel yang terorganisasi (Gamborg \& Shyluk 1981). Menurut Dodds dan Roberts (1985), pembentukan kalus pada permukaan eksplan dalam sistem kultur in vitro dapat dibagi menjadi tiga tahap perkembangan, yaitu induksi, pembelahan sel, dan diferensiasi sel. Ditambahkan oleh Suryowinoto (1996), bahwa terbentuknya kalus pada eksplan adalah dikarenakan sel-sel yang kontak dengan medium terdorong menjadi meristematik. Sel-sel yang bersifat meristematik ini selanjutnya aktif membelah dan memperbanyak diri, namun tidak berdiferensiasi, sehingga tidak terorganisir dan menjadi seperti jaringan penutup luka. Terbentuknya kalus juga disebabkan adanya rangsangan luka yang menyebabkan kesetimbangan pada dinding sel berubah arah, sebagian protoplas mengalir ke luar sehinggga mulai terbentuk kalus (Pierik 1997).

Pada penelitian ini pembentukan kalus diawali oleh terjadinya pembengkakan pada permukaan eksplan, yang kemudian dilanjutkan oleh adanya perubahan warna, struktur dan tekstur kalus. Sementara pada eksplan yang tidak membentuk kalus, baik hipokotil maupun kotiledon secara perlahan-lahan mengalami perubahan warna dari semula hijau muda menjadi kecoklatan bahkan sebagian berubah warna menjadi hitam yang menandakan eksplan tersebut mati.

Kecepatan pembentukan kalus. Hasil analisis ragam terhadap kecepatan pembentukan kalus pada eksplan hipokotil, kotiledon pangkal, kotiledon tengah dan kotiledon ujung pada pemberian berbagai taraf konsentrasi 2,4-D menunjukkan adanya interaksi yang nyata. Pengaruh konsentrasi 2,4-D dan macam eksplan terhadap kecepatan pembentukan kalus selanjutnya disajikan pada Tabel 1 .

Data yang disajikan pada Tabel 1 menunjukkan bahwa pada eksplan hipokotil inisiasi kalus terjadi dalam kurun waktu antara 7,5-10,11 hari setelah sub kultur ke media perlakuan 2,4-D (lebih cepat daripada tanpa 2,4-D yang ratarata 13,33 hari). Sementara itu pada eksplan kotiledon inisiasi kalus terjadi dalam kurun waktu yang lebih lama, yakni 13,45-15,87 hari (lebih lama dibandingkan tanpa 2,4-D yang berada pada kisaran 2,33-12,13 hari). Hal ini diduga karena hipokotil lebih banyak memiliki jaringan pengangkut dan sifat totipotensinya lebih besar daripada kotiledon. Menurut Hendaryono dan Wijayani (1994), bagian tanaman yang banyak mengandung jaringan pengangkut adalah yang paling baik untuk dijadikan sebagai bahan eksplan.

Sementara itu pada faktor zat pengatur tumbuh terlihat secara umum respon hipokotil lebih cepat dibandingkan kotiledon, terutama pada konsentrasi 1-4 mg $1^{-1}$. Pada perlakuan kontrol, antara hipokotil dengan kotiledon pangkal tidak memperlihatkan perbedaan kecepatan

Tabel 1 Pengaruh berbagai taraf konsentrasi 2,4-D dan macam eksplan terhadap kecepatan pembentukan kalus (hari)

\begin{tabular}{|c|c|c|c|c|}
\hline \multirow{2}{*}{ Konsentrasi 2,4-D } & \multicolumn{4}{|c|}{ Macam eksplan } \\
\hline & Hipokotil & Kotiledon pangkal & Kotiledon tengah & Kotiledon ujung \\
\hline \multirow{2}{*}{$0 \mathrm{mg} \mathrm{l}^{-1}$} & $13,33 \mathrm{a}$ & $12,13 \mathrm{ab}$ & 7,17 bc & $2,33 \mathrm{c}$ \\
\hline & A & A & B & B \\
\hline \multirow{2}{*}{$1 \mathrm{mg} \mathrm{l}^{-1}$} & $8,83 \mathrm{~b}$ & $13,58 \mathrm{ab}$ & $14,43 \mathrm{a}$ & $14,96 \mathrm{a}$ \\
\hline & B & A & A & A \\
\hline \multirow{2}{*}{$2 \mathrm{mg} \mathrm{l}^{-1}$} & $7,50 \mathrm{~b}$ & $14,36 \mathrm{a}$ & $14,89 \mathrm{a}$ & $14,79 \mathrm{a}$ \\
\hline & B & A & A & A \\
\hline \multirow{2}{*}{$3 \mathrm{mg} \mathrm{l}^{-1}$} & $8,69 \mathrm{a}$ & $13,76 \mathrm{a}$ & $13,45 \mathrm{a}$ & $13,86 \mathrm{a}$ \\
\hline & B & A & A & A \\
\hline \multirow{2}{*}{$4 \mathrm{mg} \mathrm{l}^{-1}$} & $9,72 \mathrm{~b}$ & $14,27 \mathrm{ab}$ & $15,87 \mathrm{a}$ & $15,51 \mathrm{a}$ \\
\hline & $\mathrm{AB}$ & A & A & A \\
\hline \multirow{2}{*}{$5 \mathrm{mg} \mathrm{l}^{-1}$} & $10,11 \mathrm{a}$ & $13,51 \mathrm{ab}$ & $13,74 \mathrm{ab}$ & $14,46 \mathrm{a}$ \\
\hline & $\mathrm{AB}$ & $\mathrm{A}$ & A & A \\
\hline
\end{tabular}


pembentukan kalus yang nyata. Fenomena yang sama juga terjadi antara eksplan hipokotil, kotiledon pangkal dan kotiledon tengah yang dikulturkan pada medium dengan $5 \mathrm{mg} \mathrm{l}^{-1}$ 2,4-D. Diduga hal ini dikarenakan kebutuhan eksplan akan zat pengatur tumbuh 2,4-D untuk menginisaisi pembentukan kalus sangat rendah, sehingga pada konsentrasi $1 \mathrm{mg} \mathrm{l}^{-1}$, sudah cukup untuk menginisiasi terbentuknya kalus, dan peningkatan konsentrasi hingga $5 \mathrm{mg} \mathrm{l}^{-1}$ tidak lagi berpengaruh. Proliferasi kalus yang lebih cepat pada eksplan yang dikulturkan pada medium tanpa 2,4-D mengindikasikan kebutuhan eksplan akan zat pengatur tumbuh telah terpenuhi secara internal, sehingga penambahan dari luar justru menjadi penghambat proliferasi kalus. Walaupun demikian, menurut Dodds dan Roberts (1985), pemberian 2,4-D pada konsentrasi 0,2-2,2 $\mathrm{mg} \mathrm{l}^{-1}$ tanpa sitokinin sangat efektif untuk induksi proliferasi kalus pada kebanyakan kultur.

Dari Tabel 1 dapat dilihat bahwa eksplan kotiledon ujung yang dikulturkan pada medium tanpa 2,4-D (kontrol) mampu membentuk kalus dalam waktu yang paling cepat, yakni rata-rata 2,33 hari setelah inisiasi kultur. Sementara itu eksplan hipokotil memperlihatkan reaksi pembentukan kalus tercepat pada seluruh taraf pemberian 2,4-D, yakni berturutturut 8,83 hari pada pemberian $1 \mathrm{mg} \mathrm{l}^{-1}$ 2,4-D, 7,5 hari pada pemberian $2 \mathrm{mg} \mathrm{l}^{-1} 2,4-\mathrm{D}, 8,69$ hari pada pemberian $3 \mathrm{mg} \mathrm{l}^{-1}$ 2,4-D, 9,72 hari pada pemberian $4 \mathrm{mg} \mathrm{l}^{-1}$ 2,4-D dan 10,11 hari pada pemberian $5 \mathrm{mg} \mathrm{l}^{-1}$ 2,4-D.

Terdapatnya interaksi pada peubah kecepatan eksplan membentuk kalus menunjukkan adanya kaitan yang erat antara macam eksplan yang digunakan dengan tingkat konsentrasi 2,4-D yang diuji. Namun demikian, proliferasi kalus pada eksplan yang dikulturkan pada medium yang dilengkapi dengan 2,4-D justru memerlukan waktu yang lebih lama daripada inisiasi kalus pada eksplan yang dikulturkan pada medium tanpa 2,4-D. Hal yang sama juga dijumpai pada kultur in vitro tanaman Thevetia peruviana (Nerium Oleander), di mana 2,4-D diketahui kurang efektif untuk menginduksi pembentukan kalus (Siwach et al. 2011), meskipun pada tanaman lain kehadiran 2,4-D justru merupakan faktor yang penting untuk proliferasi kalus (Sun et al. 2006; Burbulis et al. 2007; Satyavani et al. 2011). Diduga hal ini disebabkan oleh konsentrasi 2,4-D yang tinggi yang dapat melemahkan pengaruh auksin endogen sehingga diperlukan waktu yang lebih lama untuk terjadinya inisiasi pembentukan kalus. Ditambahkan oleh Dodds dan Robert (1985), bahwa secara umum eksplan yang mempunyai kambium tidak memerlukan penambahan zat pengatur tumbuh dari luar untuk menginisiasi terbentuknya kalus karena secara alamiah pada jaringan berkambium yang mengalami luka akan tumbuh kalus untuk menutupi luka yang terbuka. Namun pada kasus lain keberadaan kambium justru dapat menghambat inisiasi kalus bila tanpa penambahan zat pengatur tumbuh eksogen.

Persentase eksplan yang membentuk kalus. Hasil analisis ragam menunjukkan bahwa macam eksplan yang digunakan (hipokotil, kotiledon pangkal, kotiledon tengah dan kotiledon ujung) berpengaruh nyata terhadap persentase eksplan yang membentuk kalus. Pengaruh yang nyata juga diperlihatkan oleh perbedaan konsentrasi zat pengatur tumbuh 2,4-D yang diuji pada keempat macam eksplan tersebut. Akan tetapi pada percobaan ini tidak ditemukan interaksi yang nyata antara macam eksplan dengan tingkat konsentrasi 2,4-D yang dicobakan. Dengan kata lain pengaruh pemberian 2,4-D adalah sama untuk setiap taraf konsentrasi yang digunakan. Demikian juga dengan pengaruh berbagai macam sumber eksplan adalah sama untuk setiap taraf konsentrasi 2,4-D yang dicobakan. Tidak adanya interaksi antara konsentrasi 2,4-D dan sumber eksplan pada perubah persentase eksplan yang membentuk kalus diduga adalah sebagai akibat dari belum mampunya tingkat konsentrasi 2,4-D yang diuji mendorong inisiasi pembentulkan kalus. Pengaruh perbedaan macam eksplan dan perbedaan konsentrasi 2,4-D yang diuji pada percobaan ini disajikan pada Tabel 2.

Tabel 2 menunjukkan bahwa pemberian 2,4-D pada tingkat konsentrasi $1-5 \mathrm{mg}^{-1}$ nyata meningkatkan persentase eksplan yang membentuk kalus dibandingkan dengan perlakuan tanpa 2,4-D pada semua tipe eksplan yang digunakan. Hal ini menunjukkan bahwa kehadiran 2,4-D sangat penting dalam menstimulir proliferasi kalus pada permukaan eksplan. Akan tetapi di dalam kisaran konsentrasi 1-5 $\mathrm{mg} \mathrm{l}^{-1}$ tersebut tidak ditemukan adanya perbedaan pengaruh yang nyata pada semua tipe eksplan yang diuji. Selain itu, perbedaan macam eksplan ternyata juga tidak menghasilkan perbedaan yang nyata dalam hal persentase eksplan yang berkalus pada semua taraf pemberian 2,4-D. Perlakuan yang paling banyak menginduksi pembentukan kalus $(88,33 \%)$ adalah $3 \mathrm{mg} \mathrm{l}^{-1} 2$,4-D yang diberikan pada eksplan kotiledon tengah, sedangkan yang paling sedikit menginduksi kalus $(6,84 \%)$ adalah eksplan kotiledon ujung yang tidak diperlakukan dengan 2,4-D. Pembentukan kalus pada eksplan kotiledon tanaman jarak pagar juga dilaporkan oleh Mazumdar et al. (2010), di mana kalus yang terbentuk pada eksplan kotiledon meregenerasikan lebih banyak 
plantlet dibandingkan kalus yang terbentuk pada eksplan daun muda yang berasal dari bibit berumur satu dan dua minggu.

Warna kalus. Pengamatan visual terhadap warna kalus yang terbentuk pada eksplan hipokotil maupun kotiledon yang dikulturkan pada medium yang dilengkapi dengan berbagai tingkat konsentrasi 2,4-D tidak menunjukkan perbedaan yang nyata. Warna kalus yang terbentuk pada eksplan hipokotil maupun kotiledon pangkal, kotiledon tengah dan kotiledon ujung didominasi oleh warna putih, kuning muda, krem dan coklat (Tabel 3) yang menandakan adanya indikasi sifat-sifat embriogenik yang mengarah kepada perkembangan embrio somatik. Hal ini juga telah dibuktikan oleh sejumlah peneliti, misalnya pada kultur in vitro tanaman Bixa arellana, Sha-Valli-Khan et al. (2002), menemukan bahwa kombinasi NAA + BAP menghasilkan kalus berwarna putih dengan struktur remah dan permukaan mengkilap, yang kemudian berkembang menjadi kalus berwarna putih dengan struktur kompak, sebelum akhirnya meregenerasikan struktur globular berwarna hijau. Pembentukan struktur globular berwarna hijau ini merupakan tanda-tanda awal dari embriogenesis sebagaimana dilaporkan oleh Sudhersan dan Abo El Nil (2002), dan Zulkarnain (2004), pada kultur in vitro Swainsona formosa dan oleh Chakrabarty et al. (2010), pada kultur in vitro tanaman padi.

Struktur kalus. Sama halnya dengan warna, hasil pengamatan visual terhadap struktur tidak memperlihatkan adanya perbedaan yang menyolok pada kalus yang terbentuk pada eksplan hipokotil maupun kotiledon yang dikulturkan pada medium yang diberi perlakuan tingkat konsentrasi 2,4-D yang berbeda. Struktur kalus yang terbentuk, baik pada eksplan hipokotil maupun pada eksplan kotiledon (pangkal, tengah dan ujung) didominasi oleh struktur yang kompak, terutama pada eksplan hipokotil yang tidak diperlakukan dengan 2,4-D. Nampaknya struktur kalus yang terbentuk lebih dipengaruhi oleh penambahan 2,4-D di dalam medium daripada oleh penggunaan eksplan dari sumber yang berbeda (Tabel 4 dan Gambar 1).

Struktur kalus yang terbentuk pada penelitian ini adalah kompak, sama seperti halnya struktur kalus pada kultur jaringan jarak pagar yang dilaporkan oleh Sardana et al. (2000). Menurut Palama et al. (2010), struktur yang kompak merupakan salah satu penciri morfologi dari perkembangan kalus ke arah sifat-sifat embriogenik.

Tekstur kalus. Dari hasil pengamatan visual terhadap kondisi permukaan kalus yang terbentuk pada masingmasing eksplan tidak menunjukkan adanya perbedaan yang

Tabel 2 Pengaruh berbagai taraf konsentrasi 2,4-D dan macam eksplan terhadap persentase eksplan yang membentuk kalus (\%)

\begin{tabular}{|c|c|c|c|c|}
\hline \multirow{2}{*}{ Konsentrasi 2,4-D } & \multicolumn{4}{|c|}{ Macam eksplan } \\
\hline & Hipokotil & Kotiledon pangkal & Kotiledon tengah & Kotiledon ujung \\
\hline \multirow{2}{*}{$0 \mathrm{mg} \mathrm{l}^{-1}$} & $16,10 \mathrm{ab}$ & $31,06 \mathrm{a}$ & $8,80 \mathrm{~b}$ & $6,84 \mathrm{~b}$ \\
\hline & $\mathrm{B}$ & B & $\mathrm{B}$ & $\mathrm{B}$ \\
\hline \multirow{2}{*}{$1 \mathrm{mg} \mathrm{l}^{-1}$} & $79,49 \mathrm{a}$ & $66,91 \mathrm{ab}$ & $69,69 \mathrm{ab}$ & $58,45 \mathrm{~b}$ \\
\hline & A & A & A & A \\
\hline \multirow{2}{*}{$2 \mathrm{mg} \mathrm{l}^{-1}$} & $65,93 \mathrm{~b}$ & $74,22 \mathrm{ab}$ & $88,83 \mathrm{a}$ & $67,96 \mathrm{~b}$ \\
\hline & A & A & A & A \\
\hline \multirow{2}{*}{$3 \mathrm{mg} \mathrm{l}^{-1}$} & $71,54 \mathrm{a}$ & 81,19 a & $81,19 \mathrm{a}$ & $66,00 \mathrm{a}$ \\
\hline & A & A & A & A \\
\hline \multirow{2}{*}{$4 \mathrm{mg} \mathrm{l}^{-1}$} & $77,14 \mathrm{a}$ & $72,26 \mathrm{a}$ & $62,75 \mathrm{a}$ & $59,27 \mathrm{a}$ \\
\hline & A & A & A & A \\
\hline \multirow{2}{*}{$5 \mathrm{mg} \mathrm{l}^{-1}$} & $68,29 \mathrm{a}$ & $81,19 \mathrm{a}$ & $71,68 \mathrm{a}$ & $71,68 \mathrm{a}$ \\
\hline & $\mathrm{A}$ & $\mathrm{A}$ & $\mathrm{A}$ & $\mathrm{A}$ \\
\hline
\end{tabular}

Tabel 3 Warna kalus yang terbentuk pada eksplan yang dikulturkan pada medium dengan berbagai tingkat konsentrasi 2,4-D (umur enam minggu setelah subkultur)

\begin{tabular}{|c|c|c|}
\hline \multirow{2}{*}{ Konsentrasi 2,4-D } & \multicolumn{2}{|c|}{ Warna kalus pada eksplan } \\
\hline & Hipokotil & Kotiledon \\
\hline $0 \mathrm{mg} \mathrm{l}^{-1}$ & Warna kalus didominasi oleh putih & Putih dan kuning muda dengan dominasi warna putih \\
\hline $1 \mathrm{mg} \mathrm{l}^{-1}$ & Putih, kuning muda dan krem, dengan dominasi warna krem & $\begin{array}{l}\text { Putih, kuning muda, krem, kuning dan cokat dengan } \\
\text { dominasi kuning muda }\end{array}$ \\
\hline $2 \mathrm{mg} \mathrm{l}^{-1}$ & $\begin{array}{l}\text { Putih, kuning muda dan krem, dengan dominasi warna kuning } \\
\text { muda dan krem }\end{array}$ & $\begin{array}{l}\text { Putih, kuning muda, krem, kuning, hijau kekuningan dan } \\
\text { coklat dengan dominasi kuning muda }\end{array}$ \\
\hline $3 \mathrm{mg} \mathrm{l}^{-1}$ & $\begin{array}{l}\text { Putih, kuning muda, krem dan coklat dengan dominasi warna } \\
\text { krem }\end{array}$ & $\begin{array}{l}\text { Putih, kuning muda, krem, kuning, hijau kekuningan dan } \\
\text { coklat dengan dominasi kuning muda }\end{array}$ \\
\hline $4 \mathrm{mg} \mathrm{l}^{-1}$ & $\begin{array}{l}\text { Putih, kuning dan kuning muda dan , krem dengan dominasi } \\
\text { kuning muda }\end{array}$ & $\begin{array}{l}\text { Putih, kuning muda, krem, kuning, dan hijau muda } \\
\text { dengan dominasi kuning muda }\end{array}$ \\
\hline $5 \mathrm{mg} \mathrm{l}^{-1}$ & $\begin{array}{l}\text { Putih, krem, kuning muda dan coklat dengan dominasi warna } \\
\text { coklat }\end{array}$ & $\begin{array}{l}\text { Putih, kuning muda, krem, putih, kuning, hijau kuning } \\
\text { dengan dominasi kuning muda }\end{array}$ \\
\hline
\end{tabular}


Tabel 4 Struktur kalus yang terbentuk pada eksplan yang dikulturkan pada medium dengan berbagai tingkat konsentrasi 2,4-D (umur enam minggu setelah subkultur)

\begin{tabular}{cll}
\hline \multirow{2}{*}{ Konsentrasi 2,4-D } & \multicolumn{1}{c}{ Tekstur kalus pada eksplan } \\
\cline { 2 - 3 } & \multicolumn{1}{c}{ Hipokotil } & Kotiledon \\
\hline $\mathrm{mg} \mathrm{l}^{-1}$ & Kalus didominasi oleh struktur yang kompak & Remah dan kompak dengan dominasi struktur remah \\
$2 \mathrm{mg} \mathrm{l}^{-1}$ & Remah dan kompak dengan dominasi struktur kompak & Remah dan kompak dengan dominasi struktur remah \\
$3 \mathrm{mg} \mathrm{l}^{-1}$ & Remah dan kompak dengan dominasi struktur kompak & Remah dan kompak dengan dominasi struktur remah \\
$4 \mathrm{mg} \mathrm{l}^{-1}$ & Remah dan kompak dengan dominasi struktur kompak & Remah dan kompak dengan dominasi struktur remah \\
$5 \mathrm{mg} \mathrm{l}^{-1}$ & Remah dan kompak dengan dominasi struktur kompak & Remah dan kompak dengan dominasi struktur remah \\
& Remah dan kompak dengan dominasi struktur remah & Remah dan kompak dengan dominasi struktur remah \\
\hline
\end{tabular}
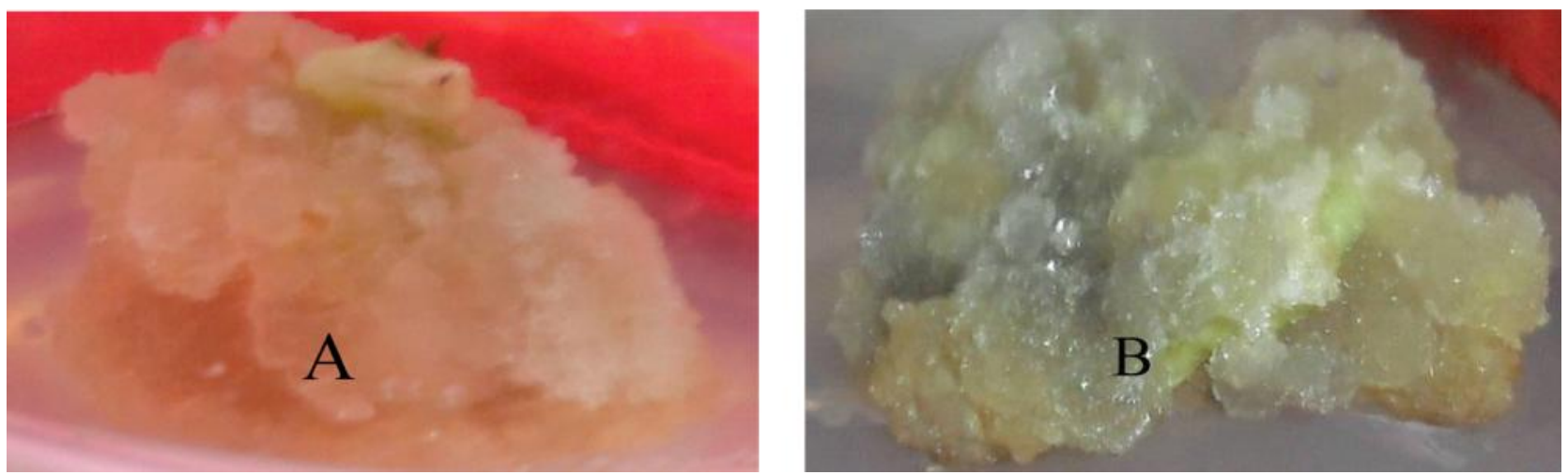

Gambar 1 Struktur kalus kompak yang terbentuk pada eksplan hipokotil dikulturkan pada medium tanpa 2,4-D (A) dan struktur kalus remah yang terbentuk pada eksplan hipokotil yang dikulturkan pada medium yang dilengkapi dengan $5 \mathrm{mg}^{-1} 2,4-\mathrm{D}$ (B)

Tabel 5 Tekstur kalus yang terbentuk pada eksplan yang dikulturkan pada medium dengan berbagai tingkat konsentrasi 2,4-D (umur enam minggu setelah subkultur

\begin{tabular}{|c|c|c|}
\hline \multirow{2}{*}{ Konsentrasi 2,4-D } & \multicolumn{2}{|c|}{ Tekstur kalus pada eksplan } \\
\hline & Hipokotil & Kotiledon \\
\hline $0 \mathrm{mg} \mathrm{l}^{-1}$ & $\begin{array}{l}\text { Sebagian besar kalus memiliki tekstur permukaan yang halus; } \\
\text { sebagian kecil kalus memiliki tekstur permukaan yang kasar }\end{array}$ & $\begin{array}{l}\text { Sebagian besar kalus memiliki tekstur permukaan } \\
\text { yang halus; sebagian kecil kalus memiliki tekstur } \\
\text { permukaan yang kasar }\end{array}$ \\
\hline $1 \mathrm{mg} \mathrm{l}^{-1}$ & $\begin{array}{l}\text { Sebagian besar kalus memiliki tekstur permukaan yang halus; } \\
\text { sebagian kecil kalus memiliki tekstur permukaan yang kasar }\end{array}$ & $\begin{array}{l}\text { Sebagian besar kalus memiliki tekstur permukaan } \\
\text { yang halus; sebagian kecil kalus memiliki tekstur } \\
\text { permukaan yang kasar }\end{array}$ \\
\hline $2 \mathrm{mg} \mathrm{l}^{-1}$ & $\begin{array}{l}\text { Sebagian besar kalus memiliki tekstur permukaan yang halus; } \\
\text { sebagian kecil kalus memiliki tekstur permukaan yang kasar }\end{array}$ & $\begin{array}{l}\text { Sebagian besar kalus memiliki tekstur permukaan } \\
\text { yang halus; sebagian kecil kalus memiliki tekstur } \\
\text { permukaan yang kasar }\end{array}$ \\
\hline $3 \mathrm{mg} \mathrm{l}^{-1}$ & $\begin{array}{l}\text { Sebagian besar kalus memiliki tekstur permukaan yang halus; } \\
\text { sebagian kecil kalus memiliki tekstur permukaan yang kasar }\end{array}$ & $\begin{array}{l}\text { Sebagian besar kalus memiliki tekstur permukaan } \\
\text { yang halus; sebagian kecil kalus memiliki tekstur } \\
\text { permukaan yang kasar }\end{array}$ \\
\hline $4 \mathrm{mg} \mathrm{l}^{-1}$ & $\begin{array}{l}\text { Sebagian besar kalus memiliki tekstur permukaan yang kasar; } \\
\text { sebagian kecil kalus memiliki tekstur permukaan yang halus }\end{array}$ & $\begin{array}{l}\text { Sebagian besar kalus memiliki tekstur permukaan } \\
\text { yang halus; sebagian kecil kalus memiliki tekstur } \\
\text { permukaan yang kasar }\end{array}$ \\
\hline $5 \mathrm{mg} \mathrm{l}^{-1}$ & $\begin{array}{l}\text { Sebagian besar kalus memiliki tekstur permukaan yang kasar; } \\
\text { sebagian kecil kalus memiliki tekstur permukaan yang halus }\end{array}$ & $\begin{array}{l}\text { Sebagian besar kalus memiliki tekstur permukaan } \\
\text { yang halus; sebagian kecil kalus memiliki tekstur } \\
\text { permukaan yang kasar }\end{array}$ \\
\hline
\end{tabular}

signifikan pada tekstur kalus yang terbentuk pada eksplan hipokotil maupun kotiledon yang dikulturkan pada medium yang dilengkapi dengan berbagai tingkat konsentrasi 2,4-D yang berbeda. Tekstur kalus yang terbentuk, baik pada eksplan hipokotil maupun pada eksplan kotiledon pada umumnya adalah halus atau licin, dan ada pula yang kasar. Pada eksplan hipokotil, pemberian 2,4-D hingga $4 \mathrm{mg} \mathrm{l}^{-1}$ menghasilkan kalus yang sebagian besar memiliki tekstur kasar; demikian pula halnya dengan kalus yang terbentuk pada eksplan hipokotil yang tidak diperlakukan dengan 2,4-D. Sebaliknya pada perlakuan $5 \mathrm{mg} \mathrm{l}^{-1} 2,4-\mathrm{D}$, kalus yang terbentuk sebagian besar memiliki tekstur yang halus. Sementara itu pada eksplan kotiledon, baik perlakuan 2,4-D maupun kontrol menghasilkan kalus dengan kondisi permukaan yang didominasi oleh tekstur yang halus (Tabel 5).

\section{SIMPULAN}

Melalui penelitian ini telah berhasil dikembangkan protokol yang efisien untuk memproduksi kalus embriogenik pada kultur in vitro tanaman jarak pagar menggunakan zat pengatur tumbuh 2,4-D dan bahan eksplan berupa potongan hipokotil dan kotiledon. Pemberian 2,4-D pada kisaran konsentrasi 1-5 $\mathrm{mg}^{-1}$ sangat penting bagi terjadinya proliferasi kalus embriogenik, namun proliferasi kalus embriogenik pada kultur in vitro tanaman jarak pagar ini 
tidak tergantung pada macam eksplan yang digunakan. Kalus yang diproliferasikan berpeluang besar untuk meregenerasikan embrio somatik bilamana disubkulturkan pada medium induksi yang sesuai. Untuk itu, tahap penelitian selanjutnya adalah optimasi medium kultur untuk menginduksi pertumbuhan embrio somatik.

\section{UCAPAN TERIMA KASIH}

Penulis mengucapkan terima kasih kepada Direktorat Penelitian dan Pengabdian kepada Masyarakat (DP2M) Ditjen Dikti yang telah membiayai penelitian ini melalui skim penelitian Strategis Nasional Tahun Anggaran 2009 (Kode Kegiatan 4257.572111 dalam DIPA Universitas Jambi).

\section{DAFTAR PUSTAKA}

Burbulis, N., Blinstrubiene, A., Sliesaravicius, A. \& Kurpiene, R. 2007. Some factors affecting callus induction on ovary culture of flax (Linum usitassimum). Biologia 53: 21-23.

Chakrabarty, D., Trivedi, P.K., Shri, M., Misra, P., Asif, M.H., Dubey, S., Kumar, S., Rai, A., Tiwari, M., Shukla, D., Pandey, A., Nigam, D., Tripathi, R.D. \& Tuli, R. 2010. Differential transcriptional expression following thidiazuroninduced callus differentiation developmental shifts in rice. Plant Biol 12: 46-59.

Datta, M.M., Mukherjee, P., Ghosh, B. \& Jha, T.B. 2007. In vitro clonal propagation of biodiesel plant (Jatropha curcas). Curr. Sci 93: 1438-1442.

Dodds, J.H. \& Roberts, L.W. 1985. Experiments in Plant Tissue Culture. Cambridge university press, Cambridge.

Gamborg, O.L. \& Shyluk, J.K. 1981. Nutrition, Media and Characteristic of Plant Cell and Tissue Culture. Dalam T. A. thorpe [ed.], Plant tissue culture: Methods and applications in agriculture, 21-44. New York: Academic Press.

Krisnamurti, B. 2006. Pengembangan bahan bakar nabati (BBN) dan kebijakan diversifikasi energi. Makalah lokakarya status teknologi budidaya jarak pagar, 11 April 2006. Pusat penelitian dan pengembangan perkebunan, Badan penelitian dan pengembangan pertanian.

Mazumdar, P., Basu, A., Paul, A. Mahanta, C. \& Sahoo, L. 2010. Age and orientation of the cotyledonary leaf explants determine the efficiency of de novo plant regeneration and Agrobacterium tumefaciens mediated transformation in Jatropha curcas L. S. Afr. J. Bot 76: 337-344.

Murashige, T. \& Skoog, F. 1962. A revised medium for rapid growth and bio assays with tobacco tissue cultures. Physiol. Plant 15: 473-497.
Novita, V. 2006. Kultur in vitro jarak pagar (Jatropha curcas L.) melalui penggunaan pemadat hidrogel (Aquasorb ${ }^{\mathrm{TM}}$ ) dan gula trehalosa $\left(\right.$ Treha $\left.^{\mathrm{TM}}\right)$. Skripsi sarjana. Fakultas pertanian institut pertanian bogor, Bogor.

Palama, T.L., Menard, P., Fock, I., Choi, Y.H., Bourdon, E., Govinden-Soulange, J., Bahut, M., Payet, B., Verpoorte, R. \& Kodja, H. 2010. Shoot differentiation from protocorm callus cultures of Vanilla planifolia (Orchidaceae): proteomic and metabolic responses at early stage. BMC Plant Biol 10: 82.

Pierik, R.L.M. 1997. In Vitro Culture of Higher Plants. Kluwer academic Publishers, The Netherlands: Dordrecht.

Rajore, S. \& Batra, A. 2005. Efficient Plant Regeneration via Shoot Tip Explant in Jatropha curcas. J. Plant Biochem. Biotech 14: 73-75.

Sardana, J., Batra, A. \& Ali, D.J. 2000. An expeditious method for regeneration of somatic embryos in Jatropha curcas Phytomorphology 50: 239-242.

Satyavani, K., Ramanathan, T. \& Gurudeeban, S. 2011. Effect of plant growth regulators on callus induction and plantlet regeneration of Bitter Apple (Citrulus colocynthis) from stem explant. Asian J. Biotech 3: 246-253.

Sha-Valli-Khan, P. S., Prakash, E. \& Rao, K.R. 2002. Callus induction and plantlet regeneration in Bixa arellana, an annattoyielding tree. In Vitro Cell. Dev. Biol -Plant 38: 186-290.

Siwach, P., Grover, K. \& Gill, A.R. 2011. The influence of plant growth regulators, explant nature, and sucrose concentration on in vitro callus growth of Thevetia peruviana Schum. Asian J. Biotech 3: 280-292.

Sudhersan, C. \& AboEl-Nil, M. 2002. Somatic embryogenesis on Sturt's desert pea (Swainsona formosa). Scientific Correspondence 83: 1074-1076.

Sujatha, M., Makkar, H.P.S. \& Becker, K. 2005. Shoot bud proliferation from axillary nodes and leaf sections of nontoxic Jatropha curcas. Plant Growth Reg 47: 83-90.

Sujatha, M. \& Muktha, N. 1996. Morphogenesis and plant regeneration from tissue culture of Jatropha curcas. Plant Cell Tiss. Org. Cult 44: 135-141.

Sun, Y., Zhang, X., Huang, C., Guo, X. \& Nie, Y. 2006. Somatic embryogenesis and plant regeneration from different wild diploid cotton (Gossypium) species. Plant Cell Rep 25: 289296.

Suryowinoto, M. 1996. Pemuliaan Tanaman secara In Vitro. Kanisius, Yogyakarta.

Taji, A., Kumar, P. \& Lakshmanan, P. 2002. In Vitro Plant Breeding. Haworth Press, Inc., New York.

Wei Qin Lu, W.D., Liao Yi Pan, S.L., Xu Ying Tang, L. \& Chen, F. 2004. Plant regeneration from epicotyl explant of Jatropha curcas. Plant Physiol. Mol. Biol 30: 475-478.

Zulkarnain. 2004. Pengaruh Ficoll dan pra-perlakuan stres terhadap embriogenesis somatik pada kultur antera Swainsona formosa. Hayati 11: 121-124. 